\title{
Optimum Insulation Thickness for the Exterior Walls of Buildings in Turkey Based on Different Materials, Energy Sources and Climate Regions
}

\author{
Cenker Aktemur*\$, Uğur Atikol* \\ * Department of Mechanical Engineering, Eastern Mediterranean University, via Mersin 10, Famagusta, N.Cyprus \\ ( cenkeraktemur41@hotmail.com,ugur.atikol@emu.edu.tr )
}

\begin{abstract}
‡Corresponding Author; Cenker Aktemur, Department of Mechanical Engineering, Eastern Mediterranean University, via Mersin 10, Famagusta, N.Cyprus, Tel: +90 5382660367

cenkeraktemur_41@hotmail.com
\end{abstract}

Received: 20.04.2017 Accepted: 21.06.2017

\begin{abstract}
Thermal insulation improves the strength and longevity of buildings by reducing energy consumption, and as a related result, improved energy use. The selection of insulation material is governed by important parameters, including the average outdoor air temperature, the thermal conductivity of the buildings and the cost of the insulation material. Increases in the thickness of the insulation material will gradually decrease the energy consumption for heating; however, the insulation thickness has an optimum value that minimises the total investment cost, and determination of this optimum value is critical for economic analysis. In this paper, a life-cycle cost analysis is presented to show the optimum insulation thickness, energy savings over a lifetime of 15 years and payback periods for six different fuels and insulation materials for four cities in Turkey selected from climate regions identified by the Turkish Thermal Insulation Standard (TS 825). Muğla (1st region), Kocaeli (2nd region), Ankara (3rd region) and Ardahan (4th region) were selected for analysis of a sandwich-type wall constructed from the following six insulation materials: extruded polystyrene, expanded polystyrene, glass wool, rock wool, polyisocyanurate and polyurethane. The calculations were also made on the basis of six different fuels, such as motorin, natural gas, propane (LPG), electricity, coal (imported), and fuel-oil No. 4. As a consequence, results demonstated that the optimum insulation thickness varies between 2.8 $\mathrm{cm}$ and $45.1 \mathrm{~cm}$, with energy savings between $16.4 € / \mathrm{m}^{2}$ and $479 € / \mathrm{m}^{2}$, and payback periods fluctuating between 0.078 and 0.860 years, depending on the city, the insulation material, and the cost of fuel.
\end{abstract}

Keywords Energy saving, optimum insulation thickness, payback period, climate region, life-cycle cost.

\section{Introduction}

Energy is a basic resource needed in all areas of human life, and it is consequently a significant component that influences economic and social development. As an energy source, fossil fuels (fuel oil, natural gas, coal, etc.) are preserving their place as primary energy resources and continue to meet a substantial portion of the world's energy requirements [1].

Statistics presented by the Turkish Ministry of Energy and Natural Resources [2] have indicated that Turkey has the potential for significant energy savings of $30 \%$ in the building sector, $20 \%$ in the industry sector and $15 \%$ in the transportation sector. In the building sector, most of the energy is consumed as heating energy, and one of the most important methods for reducing heating energy consumption is the use of insulation. The application of thermal insulation to buildings reduces the energy requirements for heating and cooling, thereby conserving fuel.

Many countries have developed new building codes and standards since the 1970s, and these standards have undergone constant renewal due to ever-evolving insulation technology. In Turkey, the TS 825 standard, "Thermal Insulation Rules in Buildings", aims to save energy by reducing the amount of energy consumed in the heating of buildings, as this represents a significant share of the energy consumption in the country. 
A substantial $25 \%$ of this energy is consumed by the residential sector, and a recent study indicates a savings potential in this sector of between 25 and $45 \%$. In the residential sector, the amount of energy used for heating is twice that used for other sources of consumption (cooking, etc.). Notably, the use of insulation material in the residential sector not only saves energy, but it also reduces the harmful emissions caused by the burning of fossil fuels.

Insulation thickness in buildings is a vital parameter in the design of exterior walls [3], as too low an insulation thickness allows heat to pass from the inside to the outside or from the outside to the inside, resulting in a negative effect on thermal comfort and energy savings. Increasing the insulation thickness in the walls reduces heat loss and the subsequent heating load and fuel cost; however, an increase in insulation thickness results in an increase in insulation investment costs.

The total cost, which is the sum of the costs of the fuel consumption of the building and the insulation, decreases to a certain value and then increases beyond that level [4]. For this reason, it is important that in the optimization of insulation thickness the environment in which the building is located, the type of fuel and the choice of insulation material are all takeb into account.

\section{A review on the Determination of Optimum Insulation Thickness}

The previous studies on the efficient use of energy reported in the literature were generally aimed at determining the optimum insulation thickness and a simple payback period. For example, Dombayc1 et al. [5] calculated the optimum insulation thickness for Denizli based on the use of two different insulants and five different fuel types. Similarly, Çomaklı and Yüksel [6] calculated the optimum insulation thickness for the three coldest cities in the fourth DD region of Turkey in accordance with the TS Standard no 825. Bolattürk [7] carried out a comparative analysis to determine the optimum insulation thickness on the outside walls of buildings, whereas Kaynaklı [8] determined the optimum insulation thicknesses for different types of fuel, such as natural gas, coal, fuel oil, propane (LPG) and electricity in a prototype building in Bursa. Kaynaklı and Yamankaradeniz [9] determined the annual fuel costs for the use of natural gas as a fuel with different insulation thicknesses for two different wall types in various climate regions in Turkey.

Gölcü et al. [10] used a life-cycle cost analysis method to calculate the optimum external wall insulation thicknesses, the energy savings and simple payback periods for heating of buildings in the Denizli province of Turkey, based on the use of different energy sources, such as imported coal and fuel oil. Uçar and Balo [11] used a degree-day method and a life-cycle cost analysis method to calculate the optimum insulation thicknesses of the outer walls, the energy savings and simple payback periods for four cities located in four different regions of Turkey (Mersin, Elazığ, Şanlıurfa and Bitlis), five different energy types (coal, natural gas, fuel-oil, LPG and electricity) and three different insulation materials (expanded polystyrene, extruded polystyrene, and rock wool).
Kon and Yüksel [12] conducted a complex three-part study (focused on business and service bureaus, training halls and textile production) in Balikesir province to determine the optimum insulation thickness and the achievable savings for the exterior walls of buildings. Ozkan and Onan [13], using a new approach, investigated the effects of altering the glazing area percentage of windows, which ranged from 10 to $50 \%$, on the optimum insulation thickness for four regions in Turkey.

Mahlia et al. [14], who analysed the relationship between the thickness of the insulation materials selected for the building walls and the thermal conductivity, found a polynomial function that showed a non-linear relationship between the thermal conductivity and the optimum thickness of the insulation material. This particular study was designed for Malaysia, which is a hot and humid country and does not typically undergo major changes in atmospheric temperature. Kürekçi [15] carried out a similar study to determine the optimum insulation thicknesses required in Turkey's 81 provincial centres, with calculations made based on four different fuels (natural gas, coal, fuel-oil and propane (LPG) and 5 different insulation materials (extruded polystyrene, expanded polystyrene, glass wool, rock wool and polyurethane).

Ulaş [16] investigated four different heat insulation regions and three different types of fuel for the amount of carbon dioxide released into the atmosphere as a result of the combustion of fuel consumed. The optimum insulation thickness was compared with the insulation thicknesses determined according to TS 825 calculation method. Three different insulation materials (Expanded Polystyrene, Extruded Polystyrene and Glass Wool) and three different fuels (Lignite and Mineral Coal, Natural Gas and Fuel-Oil) were used. The lowest carbon dioxide emissions were found when natural gas is used for Region 1, while the highest carbon dioxide emissions were detected when lignite and coal are used in Region 4.

Hasan [17] calculated the optimum insulation thicknesses for four types of fuel and two insulating materials for Palestine by using the degree-of-day and life cost analysis approach. As a result, he pointed out that the period of payback period for stone wool insulation is between 1.3-2.3 years, for polystyrene insulation is 1-1.7 years. Özel and P1ht1lı [18] calculated the optimum thickness of the insulation applied to the exterior walls for Adana, Elazı ğ, Erzurum, İstanbul and İzmir considering the heating and cooling degree-day values.

Gürel and Daşdemir [19] calculated the optimum insulation thicknesses and energy savings for heating and cooling loads in Aydin, Edirne, Malatya and Sivas selected from different climatic regions. XPS and EPS were chosen as insulation material in the outer wall. As fuel, natural gas is used for heating and electricity is used for cooling. The results demostrated that the optimum thickness varies between 0.036 and $0.1 \mathrm{~m}$ depending on the insulation material and province selected, the energy savings are between $12.08 € / \mathrm{m}^{2}$ and $58.28 € / \mathrm{m}^{2}$, and payback period vary between 1.5 and 2.52 years. 


\section{Mathematical Method}

\subsection{Heating degree-day approach}

The base temperature is the temperature at which the generated inner temperature will compensate for the heat loss from the outside. Consequently, the assessment of HDD values depends upon numerous elements including various structural features such as the category of walling, the level of insulation, the presence of air leakage, accessibility of incident sunlight, and so on, as well as the specific climatic circumstances and the personal inclinations of the people using the building. Thus, the number of degre-days is calculated according to the equation (1).

$H D D=\sum_{j=1}^{N}\left(T_{b}-T_{o, j}\right)$ if $\left(T_{o}<T_{b}\right)$

$H D D=0$ if $\left(T_{o}>T_{b}\right)$

where $T_{b}$ is base temperature, $T_{o, j}$ is daily mean outside air temperature recorded at a meteorology station, $N$ is the number of days provided that $T_{o}<T_{b}$ in a heating season. Therefore, heating degree-day values are calculated as $T_{o}<$ $T_{b}$. As it can be seen from equation (2), HDD values only take on positive values.

Turkey is divided into four climate regions for each province according to heating degree-day numbers identified by TS 825 on the map indicated in Fig. 1 below. Region 1 represents the least energy requirement for heating and Region 4 represents the region where energy is needed the most. In this study, the base temperature for heating purpose is assumed as $17.5^{\circ} \mathrm{C}$ to calculate heating degree-day values. In the study, insulation analysis was performed for sandwichtype insulated wall-type insulated wall structure using the HDD values of Muğla, Kocaeli, Ankara and Ardahan, which are determined from General of State Meteorology Affairs. Properties and number of heating degree-days of the cities referred to in this study are given in Table 1 .

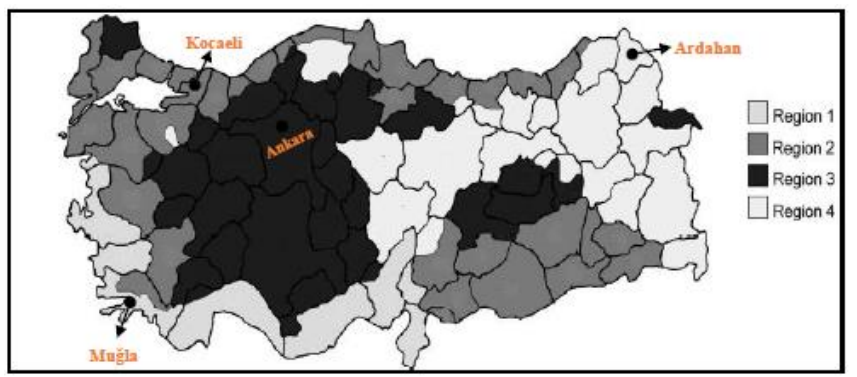

Fig. 1. HDD regions identified by TS 825 in Turkey [21].

The amount of energy required to heat a building, relative to a specific base or reference temperature, is evaluated by the heating degree day (HDD) method.
Table 1. Climate regions and certain data for selected cities

\begin{tabular}{|c|c|c|c|c|c|}
\hline Region & City & $\begin{array}{c}\text { Altitude } \\
(\mathbf{m})\end{array}$ & $\begin{array}{c}\text { Longitude } \\
\left.\mathbf{(}^{\mathbf{}}\right)\end{array}$ & $\begin{array}{c}\text { Latitude } \\
\left(\mathbf{(}^{\mathbf{}}\right)\end{array}$ & $\begin{array}{c}\text { HDD } \\
\mathbf{(}^{\mathbf{O}} \mathbf{C}- \\
\mathbf{d a y})\end{array}$ \\
\hline $1^{\text {st }}$ & Muğla & 661 & $28.36 \mathrm{E}$ & $37.22 \mathrm{~N}$ & 1560 \\
\hline $2^{\text {nd }}$ & Kocaeli & 465 & $29.88 \mathrm{E}$ & $40.85 \mathrm{~N}$ & 1762 \\
\hline $3^{\text {rd }}$ & Ankara & 896 & $32.86 \mathrm{E}$ & $39.93 \mathrm{~N}$ & 2425 \\
\hline $4^{\text {th }}$ & Ardahan & 1915 & $42.78 \mathrm{E}$ & $41.13 \mathrm{~N}$ & 4687 \\
\hline
\end{tabular}

\subsection{The structure of the external walls}

Heat is broadly lost to the building via the exterior walls, windows, floors and ceilings and by ingress of air from the exterior. The majority of heat is lost to buildings through exterior walls constructed of conventional building materials such as perforated bricks, concrete and wood. Hence, the present work took into consideration only heat loss via the external walls in order to evaluate the optimum insulation thickness [22]. The thermal insulation on the outer walls is applied in three ways; internally externally or sandwitched between two walls. Insulation applications are usually carried out by a wall model with a composite structure called a sandwich-type wall. The structure of sandwich-type wall makes up of $3 \mathrm{~cm}$ internal plaster, $22 \mathrm{~cm}$ horizontal hollow brick, insulation material, $22 \mathrm{~cm}$ horizontal hollow brick, and $4 \mathrm{~cm}$ external plaster. This structure is used in calculations for analyzed cities. In this case study, a sandwich-type insulated wall depicted in Fig. 2 is examined considering six different insulation materials, namely Extruded polystyrene (XPS), Expanded polystyrene (EPS), Glass wool (GW), Rock wool (RW), Polyisocyanurate (PIR), and Polyurethane (PUR) are pointed out in Table 2 with their thermal conductivities and costs.

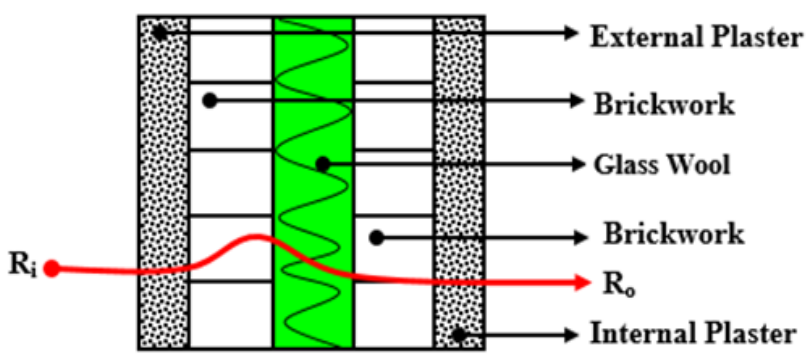

Fig. 2. A cross-view of the sandwich-type insulated wall structure.

Table 2. Parameters of the insulation wall [23]

\begin{tabular}{|l|c|c|}
\hline Insulation material & $\mathbf{k}_{\text {ins. }}(\mathbf{W} / \mathbf{m K})$ & $\mathbf{C}_{\text {ins. }}\left(\boldsymbol{(} / \mathbf{m}^{\mathbf{3}}\right)$ \\
\hline Extruded polystyrene (XPS) & 0.031 & 300 \\
\hline Expanded polystyrene (EPS) & 0.039 & 200 \\
\hline Glass wool (GW) & 0.040 & 100 \\
\hline Rock wool (RW) & 0.040 & 145 \\
\hline Polyurethane (PUR) & 0.024 & 450 \\
\hline Polyisocyanurate (PIR) & 0.023 & 400 \\
\hline
\end{tabular}




\subsection{Heating load for external walls}

The transfer of heat into and out of the building, via the walls, involves the processes of radiation, conduction and convection. Solar radiation can be directly absorbed at the outer surface of the walls to produce heat which is then transferred through the bulk of the wall. Further heat can be transferred by convective movements of the atmosphere in contact with both exterior and interior wall surfaces. The amount of heat lost per unit surface area of external wall is obtained from the equation (3) [24].

$Q=U \times\left(T_{i}-T_{o}\right)$

where $U$ is the total heat transfer coefficient of the wall, $T_{i}$ is the indoor air temperature and $T_{o}$ is the outdoor air temperature.

The overall heat transfer coefficient of the outside wall $(U)$ that includes a layer of insulation is given by equation (4) [23].
$U=\frac{1}{R_{i}+R_{w}+\frac{x_{i n s}}{k_{i n s}}+R_{0}}$

where $R_{i}$ and $R_{0}$ are the heat transfer coefficients of the inside and outside environment respectively, $R_{w}$ is the thermal resistance of the wall without insulation, $x$ and $k$ are the thickness and thermal conductivity coefficient of the insulation material, respectively. The values of $R_{i}=0.13$ $\mathrm{W} / \mathrm{m}^{2} \mathrm{~K}$ and $R_{o}=0.04 \mathrm{~m}^{2} \mathrm{~K} / \mathrm{W}$ are used for heat transfer coefficients on the inside and outside of the building.

Total resistance of the non-insulated wall layer $R_{w, t}$ is determined by help of the equation (5) below and a brief summary of physical and thermal properties of building construction materials is presented in Table 3 below.

$$
R_{w, t}=R_{i}+R_{w}+R_{o}
$$

Table 3. Physical and thermal properties of building construction materials of the external wall

\begin{tabular}{|c|c|c|c|}
\hline Wall structure & Thickness (m) & $\mathbf{k}(\mathbf{W} / \mathbf{m K})$ & $\mathbf{R}\left(\mathbf{m}^{2} \mathbf{K} / \mathbf{W}\right)$ \\
\hline Internal plaster & 0.03 & 0.87 & 0.034 \\
\hline Hollow brick & 0.22 & 0.84 & 0.262 \\
\hline Insulation & \multicolumn{3}{|c|}{ See Table 2 for further information } \\
\hline Hollow brick & 0.22 & 0.84 & 0.262 \\
\hline External plaster & 0.04 & 0.87 & 0.046 \\
\hline $\mathrm{R}_{\mathrm{i}}$ & & & 0.13 \\
\hline $\mathrm{R}_{\mathrm{o}}$ & & & 0.04 \\
\hline $\mathrm{R}_{\mathrm{w}, \mathrm{t}}$ & & & 0.774 \\
\hline
\end{tabular}

then, total heat transfer coefficient $U$ is expressed as in the following equation (6).

$U=\frac{1}{R_{w, t}+\frac{x_{\text {ins }}}{k_{\text {ins }}}}$

Using the HDD concept, annual heat loss for a unit surface area can be found through the following equation (7) [25].

$$
q_{\text {year }}=86400 \times H D D \times U
$$

The annual amount of energy required for heating by the heat loss from the unit surface of the outer wall is obtained by dividing the annual heat loss by the efficiency $(\eta)$ of the combustion system.

$E=\frac{q_{y e a r}}{\eta}$

Equation (7) is substituted into equation (8), then the amount of annual heating energy requirement can be written the following equation (9) [11].

$E_{H}=\frac{86400 \times H D D}{\left(R_{w, t}+\frac{x_{\text {ins. }}}{k_{\text {ins. }}}\right) \times \eta}$

LHV, efficiencies and prices of various heating systems are indicated in Table 4 below.

\begin{tabular}{|c|c|c|c|}
\hline Fuel type & LHV & $\eta(\%)$ & Fuel cost $\left(c_{f}\right)$ \\
\hline Coal (imported) & $29.295 \times 10^{6} \mathrm{~J} / \mathrm{kg}$ & 66 & 0.94 も/kg \\
\hline Natural gas & $34.526 \times 10^{6} \mathrm{~J} / \mathrm{m}^{3}$ & 90 & 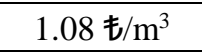 \\
\hline Propane (LPG) & $46.453 \times 10^{6} \mathrm{~J} / \mathrm{kg}$ & 88 & 6.8 $/ \mathrm{kg}$ \\
\hline Fuel-oil no:4 & $40.594 \times 10^{6} \mathrm{~J} / \mathrm{kg}$ & 80 & 2.77 も/kg \\
\hline Motorin & $42.636 \times 10^{6} \mathrm{~J} / \mathrm{kg}$ & 83 & 5.49 も/kg \\
\hline Electricity & $3.599 \times 10^{6} \mathrm{~J} / \mathrm{kWh}$ & 99 & 0.42 も $/ \mathrm{kWh}$ \\
\hline
\end{tabular}

Table 4. Fuel costs $\left(C_{f}\right)$ and lower heating values (LHV) of heating systems and efficiencies of fuel ( $\left.\eta\right)$ [26] 


\subsection{Annual energy cost and calculation of the optimum insulation thickness}

The annual fuel cost is obtained by multiplying the amount of fuel to be used per year by the unit price of the fuel. The annual cost of fuel for unit surface area, which is the unit price of the fuel, can be calculated the following equation (11).

$C_{H}=m_{f} \cdot C_{f}$

Equation (11) can be rewritten as equation (12):

$$
C_{H}=\frac{86400 \times H D D \times c_{f} \times P W F}{\left(R_{w, t}+\frac{x_{i n s .}}{k_{\text {ins. }}}\right) \times \eta \times \mathrm{LHV}}
$$

where PWF is present value and $C_{f}$ is the fuel cost in $€ / \mathrm{kg}$, $€ / \mathrm{m}^{3}$ or $€ / \mathrm{kWh}$ depending on the fuel type, which can be taken from Table 4 above.

Expected lifetime (LT) and the PWF must be evaluated together while calculating the total heating cost. The PWF value depends on the actual interest rate (r) and time. The interest rate adjusted for inflation rate $\left(i^{*}\right)$ is given by the following equations (13) and (14) [21, 27].

$i^{*}=\frac{i-g}{i+g}, \quad$ for $\quad(i>g)$

$i^{*}=\frac{i+g}{i-g}, \quad$ for $\quad(i<g)$

where $\mathrm{g}$ is the inflation rate. In this case, PWF is determined by aid of the equation (15):

$P W F=\frac{\left(1+i^{*}\right)^{L T}-1}{i^{*}\left(1+i^{*}\right)^{L T}}$

where LT is the expected lifetime, which is taken to be 15 years. If $\mathrm{i}=\mathrm{g}$, then

$P W F=\frac{L T}{1+i}$

Lifetime, interest and inflation rate values employed in calculating the PWF are summarized in Table 5.

Table 5. Parameters used in the calculations

\begin{tabular}{|c|c|}
\hline Interest rate (i) & $9 \%$ \\
\hline Inflation rate (g) & $8.53 \%$ \\
\hline Lifetime (LT) & 15 -years \\
\hline Present worth factor (PWF) & 8.58 \\
\hline
\end{tabular}

Since the cost of insulation will increase in proportion to the unit thickness of the insulation material, the cost of insulation is given by the following equation (17).

$C_{\text {ins }}=C_{y} \cdot x_{\text {ins }}$
The total cost of heating the insulated building in Turkish Lira is given by the equation (18) below.

$C_{t, H}=C_{f} \cdot P W F+C_{t, i n s}$

Equation (12) is substituted into equation (18) and then the total heating cost can be written as indicated in the following equation (19).

$C_{t, H}=\frac{86400 \times H D D \times C_{f} \times P W F}{\left(R_{w, t}+\frac{x_{i n s .}}{k_{\text {ins. }}}\right) \times \eta \times \mathrm{LHV}}+C_{y} \times x_{\text {ins }}$

Optimum insulation thickness minimizing the total heating cost is calculated with the equation (20) below $[6,7,10,11$, 27].

$$
\begin{aligned}
X_{o p t, H}=293.94 & \times\left(\frac{H D D \times C_{f} \times P W F \times k_{i n s}}{L H V \times C_{y} \times \eta}\right)^{\frac{1}{2}} \\
& -k_{\text {ins }} \\
& \times R_{w, t}
\end{aligned}
$$

As shown by equation (20) above, optimum insulation thickness varies depending on the properties of the wall, insulation material, unit price of fuel, PWF, inflation rate, the fuel type, and the total number of heating degrees-days.

\subsection{Simple payback period}

In situations where interest rates vary, it is important to consider the period of payback as it is not possible to estimate the long-term interest rate. Interest rates can be estimated to be sensitive for up to 1-2 years. The simple payback period (SPP) is not a method of measuring the economic viability of an investment, but is a method that calculates how many years' incomes will meet expenses. The $\mathrm{C}_{\mathrm{H}}$ in the formula represents pre-insulation heating energy costs. Annual total net saving amount for buildings heated is calculated with equation (21) and $\mathrm{SPP}_{\mathrm{H}}$ is calculated with equation (22) [21].

$A_{\text {year }, H}=C_{H}-C_{t, H}$

$\mathrm{SPP}_{\mathrm{H}}=\frac{C_{\text {ins. }}}{A_{\text {year }, \mathrm{H}}}$

$\mathrm{SPP}_{\mathrm{H}}$ is only meaningful for short periods (typically less than one year) as it does not take into account the time value of money.

\section{Results and Discussions}

As a widely-used approach for facilitating normalization in the context of energy consumption, the present research employed the HDD technique to determine the optimum insulation thickness for application to the outer walls. Drawing on a sample of four Turkish cities, each situated in a contrasting area of the country characterized by varying climatic conditions, optimum insulation thickness was identified for six categories of fuel and insulation resources. In turn, it was possible for the researcher to determine optimum insulation thickness, energy consumption, and payback period after the insulation materials had been applied to the exterior walls. 
Ultimately, insulation and fuel expenses were identified as the central dimensions which impact the overall yearly expense associated with insulating a building, and it should be noted that the loss or gain of thermal energy is lowered for a building that has been insulated. Furthermore, the degree to which the applied insulation is thick is directly and proportionally correlated with the level of heat loss or gain, thereby meaning that overall expense falls in conjunction with a decrease in the thermal energy requirement to heat the unit area. Nevertheless, the fact should not be overlooked that the expense required to apply insulation increases at an almost exponential rate when the thickness of the insulation rises. Subsequently, owing to the elevated insulation expense, overall expense increases significantly once a notable threshold - namely, the optimum insulation thickness figure has been exceeded. If insulation can be applied at the optimum insulation thickness, the overall cost is minimized to the greatest possible degree. The fuel cost, the insulation cost and the total heating cost relationship with the change of the thickness of the insulation material for selected cities over the 15-year lifetime are shown in the following Fig. 3. As can be seen from Fig. 3, the insulation cost increases linearly while the fuel cost decreases with increasing insulation thickness.

The total cost shows a similar tendency to change depending on the insulation thickness, but the total cost for Ardahan is much higher than for the other cities for all six insulation materials. The total cost of the sum of the cost of fuel and insulation is reduced by a certain value and then increased after this level. In the equation given in (19), the annual heating cost for the non-insulated wall was calculated by taking $\mathrm{x}=0$. Then, in the same equation, total insulation cost was found for the insulated wall by determining the insulation thickness. The heating cost obtained for noninsulated wall of the building is subtracted from the heating cost obtained for the insulated building, and then the annual saving is calculated.

Energy savings are directly proportional to the climatic conditions of the region, and the energy savings for sandwichtype wall. Fig. 4 shows the comparison of energy savings of all insulation materials examined for four cities in case heating requirement is only supplied by Propane (LPG) as an energy source. The optimum insulation thickness is achieved when the savings start to drop as the thickness of insulation material is increased.

The energy saving value becomes maximum at the optimum insulation thickness point. For example, in Ankara, the energy savings is nearly $198.3 € / \mathrm{m}^{2}$ at a certain thickness for Polyurethane (PUR), whilst the energy savings for Polyisocyanurate (PIR) is about $288.5 € / \mathrm{m}^{2}$. The energy savings in Kocaeli reaches maximum value which is roughly $192 € / \mathrm{m}^{2}$ for Polyurethane (PUR) at the optimum insulation thickness. As can be seen from Fig. 4, annual savings for EPS remain the same after a certain insulation thickness (about $0.18 \mathrm{~m})$.
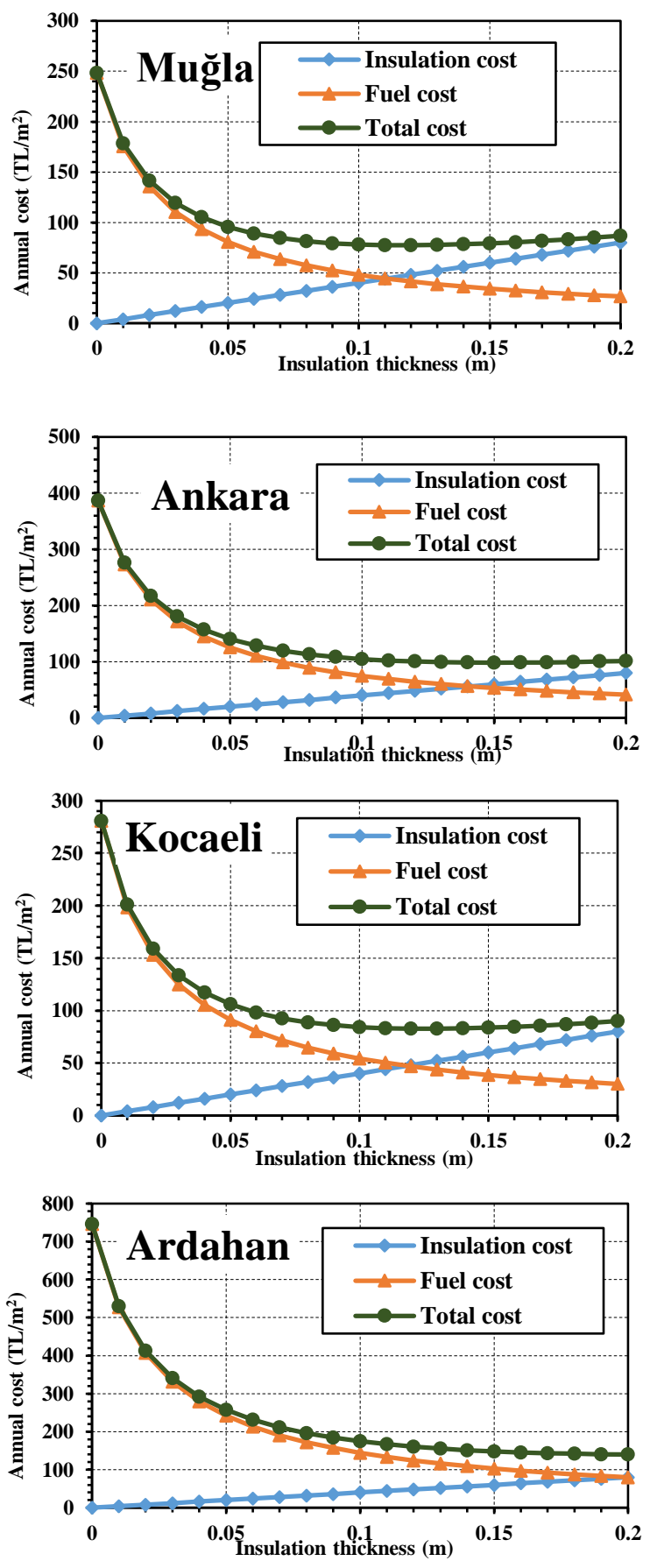

Fig. 3. Effect of insulation thickness of Polyurethane (PUR) on the total cost in case heating energy requirement is only using Propane (LPG) in selected cities. 

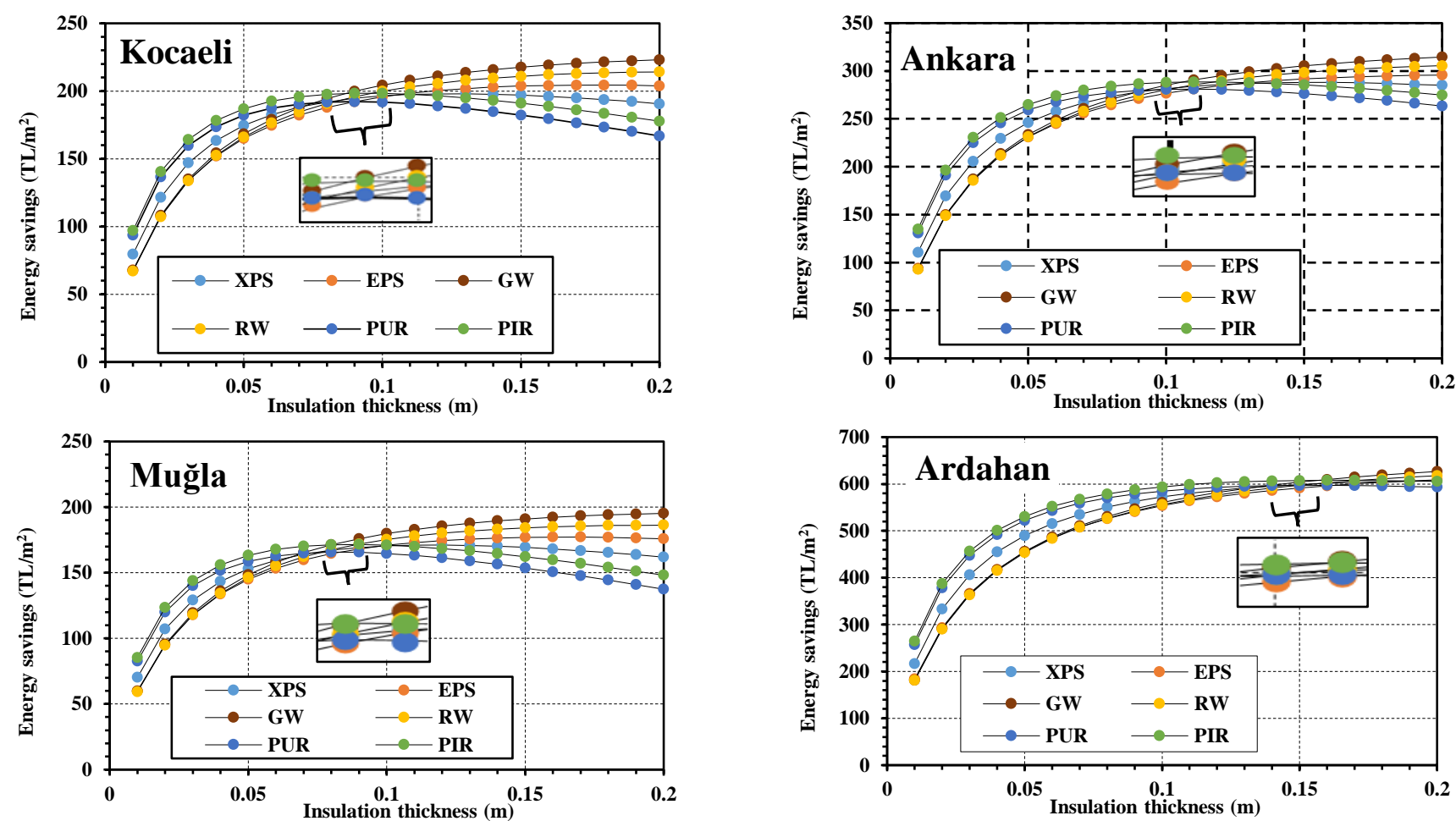

Fig. 4. Comparison of energy savings of all insulation materials for four cities in case heating requirement is only supplied by Propane (LPG) in selected cities.

Optimum insulation thickness is the value that makes the total cost minimum. The optimum insulation thicknesses, energy savings and payback periods for various fuels were calculated for Muğla, Kocaeli, Ankara, and Ardahan selected from four heating degree-day regions, which are given in Tables 6-9. To summarize Tables 6-9, while energy savings are obtained with $117.7 € / \mathrm{m}^{2}$ for $\mathrm{RW}$ at the optimum insulation thickness (about $24.8 \mathrm{~cm}$ ) in case of using Propane (LPG) as an energy source in Muğla, energy savings are achieved with $479 € / \mathrm{m}^{2}$ for RW at the optimum insulation thickness (about $45 \mathrm{~cm}$ ) in case of using propane (LPG) as an energy source in Ardahan. Whereas it is determined that the highest energy savings were achieved using Propane (LPG) for all insulation material types, it is detected that the lowest energy savings were attained using natural gas for all insulation material types. Fig. 5 presents optimum insulation thickness versus various heating systems for different insulation materials in cities of Muğla, Kocaeli, Ankara, and Ardahan.

The variation at the optimum insulation thicknesses determined by HDDs for natural gas and various insulation materials is shown in Fig. 6 below. As the number of HDDs increases, the optimum insulation thickness enhances in parallel and it is clearly seen that glass wool $(\mathrm{GW})$ is significantly higher than the rest insulation materials due to its high thermal conductivity. It is also seen that the optimum insulation thickness is higher in the cases where the HDD value is large, that is, in colder climates. When using EPS as an insulation material, the optimum insulation thickness decreases compared to RW and GW. 
INTERNATIONAL JOURNAL Of ENGINEERING TECHNOLOGIES-IJET

Cenker Aktemur et al., Vol.3, No.2, 2017

Table 6. Optimum insulation thickness, energy savings and payback periods of Muğla for various fuels

\begin{tabular}{|l|c|c|c|c|c|c|}
\hline \multirow{2}{*}{ Fuel type } & \multicolumn{7}{|c|}{ Muğla } \\
\cline { 2 - 7 } & \multicolumn{7}{|c|}{ Optimum insulation thickness $(\boldsymbol{m})$} \\
\cline { 2 - 7 } & XPS & EPS & PUR & PIR & RW & GW \\
\hline Natural gas & 0,041 & 0,060 & 0,028 & 0,031 & 0,097 & 0,076 \\
\hline LPG (propan) & 0,118 & 0,165 & 0,083 & 0,088 & 0,248 & 0,201 \\
\hline Motorin & 0,113 & 0,158 & 0,080 & 0,084 & 0,238 & 0,193 \\
\hline Electricity & 0,096 & 0,134 & 0,067 & 0,071 & 0,204 & 0,164 \\
\hline Fuel-oil no.4 & 0,078 & 0,110 & 0,055 & 0,058 & 0,169 & 0,135 \\
\hline Coal (imported) & 0,053 & 0,076 & 0,037 & 0,040 & 0,120 & 0,095 \\
\hline & \multicolumn{7}{|c|}{ Energy savings (TL/m2) } & \\
\hline Natural gas & 16,828 & 17,391 & 16,399 & 16,861 & 19,774 & 18,426 \\
\hline LPG (propan) & 106,470 & 109,070 & 104,161 & 106,633 & 117,731 & 113,151 \\
\hline Motorin & 98,302 & 100,774 & 96,111 & 98,457 & 109,039 & 104,663 \\
\hline Electricity & 71,591 & 73,600 & 69,829 & 71,717 & 80,434 & 76,795 \\
\hline Fuel-oil no.4 & 49,007 & 50,544 & 47,679 & 49,102 & 55,926 & 53,035 \\
\hline Coal (imported) & 25,095 & 25,973 & 24,375 & 25,148 & 29,325 & 27,479 \\
\hline & \multicolumn{7}{|c|}{ Payback period (years) } & \\
\hline Natural gas & 0,810 & 0,748 & 0,860 & 0,806 & 0,770 & 0,446 \\
\hline LPG (propan) & 0,357 & 0,324 & 0,388 & 0,355 & 0,326 & 0,190 \\
\hline Motorin & 0,371 & 0,337 & 0,403 & 0,369 & 0,339 & 0,197 \\
\hline Electricity & 0,432 & 0,392 & 0,469 & 0,429 & 0,394 & 0,230 \\
\hline Fuel-oil no.4 & 0,516 & 0,468 & 0,559 & 0,513 & 0,470 & 0,274 \\
\hline Coal (imported) & 0,693 & 0,633 & 0,745 & 0,689 & 0,641 & 0,373 \\
\hline
\end{tabular}

Table 7. Optimum insulation thickness, energy savings and payback periods of Kocaeli for various fuels

\begin{tabular}{|l|c|c|c|c|c|c|}
\hline \multirow{2}{*}{ Fuel type } & \multicolumn{7}{|c|}{ Kocaeli } \\
\cline { 2 - 7 } & \multicolumn{7}{|c|}{ Optimum insulation thickness $(\boldsymbol{m})$} \\
\cline { 2 - 7 } & XPS & EPS & PUR & PIR & RW & GW \\
\hline Natural gas & 0,045 & 0,065 & 0,031 & 0,034 & 0,105 & 0,082 \\
\hline LPG (propan) & 0,127 & 0,177 & 0,090 & 0,095 & 0,265 & 0,215 \\
\hline Motorin & 0,122 & 0,170 & 0,086 & 0,091 & 0,255 & 0,207 \\
\hline Electricity & 0,103 & 0,144 & 0,073 & 0,077 & 0,218 & 0,176 \\
\hline Fuel-oil no.4 & 0,084 & 0,118 & 0,059 & 0,063 & 0,181 & 0,146 \\
\hline Coal (imported) & 0,058 & 0,082 & 0,040 & 0,043 & 0,130 & 0,103 \\
\hline & \multicolumn{7}{|c|}{ Energy savings (TL/m2) } \\
\hline Natural gas & 17,126 & 20,060 & 14,512 & 17,310 & 29,772 & 24,647 \\
\hline LPG (propan) & 181,205 & 189,021 & 174,090 & 181,703 & 213,809 & 200,920 \\
\hline Motorin & 165,952 & 173,459 & 159,121 & 166,429 & 197,296 & 184,897 \\
\hline Electricity & 116,309 & 122,702 & 110,506 & 116,715 & 143,097 & 132,471 \\
\hline Fuel-oil no.4 & 74,754 & 80,016 & 69,993 & 75,088 & 96,920 & 88,091 \\
\hline Coal (imported) & 31,597 & 35,281 & 28,290 & 31,829 & 47,313 & 40,994 \\
\hline \multicolumn{7}{|c|}{ Payback period (years) } \\
\hline Natural gas & 0,796 & 0,649 & 0,972 & 0,785 & 0,511 & 0,333 \\
\hline LPG (propan) & 0,210 & 0,187 & 0,232 & 0,208 & 0,180 & 0,107 \\
\hline Motorin & 0,220 & 0,196 & 0,244 & 0,218 & 0,187 & 0,112 \\
\hline Electricity & 0,266 & 0,235 & 0,296 & 0,264 & 0,221 & 0,133 \\
\hline Fuel-oil no.4 & 0,338 & 0,296 & 0,381 & 0,335 & 0,271 & 0,165 \\
\hline Coal (imported) & 0,550 & 0,466 & 0,642 & 0,544 & 0,397 & 0,250 \\
\hline
\end{tabular}


Table 8. Optimum insulation thickness, energy savings and payback periods of Ankara for various fuels

\begin{tabular}{|l|c|c|c|c|c|c|}
\hline \multirow{3}{*}{ Fuel type } & \multicolumn{7}{|c|}{ Insulation material type } \\
\cline { 2 - 7 } & \multicolumn{7}{|c|}{ Optimum insulation thickness (m) } \\
\cline { 2 - 7 } & XPS & EPS & PUR & PIR & RW & GW \\
\hline Natural gas & 0,057 & 0,081 & 0,040 & 0,043 & 0,128 & 0,102 \\
\hline LPG (propan) & 0,153 & 0,212 & 0,108 & 0,114 & 0,316 & 0,257 \\
\hline Motorin & 0,147 & 0,204 & 0,104 & 0,110 & 0,304 & 0,248 \\
\hline Electricity & 0,125 & 0,174 & 0,088 & 0,093 & 0,261 & 0,212 \\
\hline Fuel-oil no.4 & 0,103 & 0,144 & 0,073 & 0,077 & 0,218 & 0,176 \\
\hline Coal (imported) & 0,072 & 0,102 & 0,050 & 0,054 & 0,157 & 0,126 \\
\hline & 39,709 & 42,607 & 37,126 & 39,891 & 52,202 & 47,139 \\
\hline Natural gas & 288,078 & 295,797 & 281,051 & 288,570 & 320,278 & 307,549 \\
\hline LPG (propan) & 265,662 & 273,076 & 258,915 & 266,133 & 296,617 & 284,372 \\
\hline Motorin & 192,192 & 198,506 & 186,460 & 192,593 & 218,649 & 208,154 \\
\hline Electricity & 129,778 & 134,976 & 125,075 & 130,108 & 151,671 & 142,951 \\
\hline Fuel-oil no.4 & 63,094 & 66,734 & 59,828 & 63,324 & 78,618 & 72,376 \\
\hline Coal (imported) & \multicolumn{7}{|c|}{ Payback period (years) } & \\
\hline & 0,433 & 0,382 & 0,483 & 0,429 & 0,356 & 0,215 \\
\hline Natural gas & 0,159 & 0,144 & 0,174 & 0,158 & 0,143 & 0,084 \\
\hline LPG (propan) & 0,166 & 0,150 & 0,181 & 0,165 & 0,149 & 0,087 \\
\hline Motorin & 0,195 & 0,176 & 0,213 & 0,194 & 0,173 & 0,102 \\
\hline Electricity & 0,238 & 0,213 & 0,261 & 0,236 & 0,208 & 0,123 \\
\hline Fuel-oil no.4 & 0,342 & 0,304 & 0,379 & 0,340 & 0,290 & 0,173 \\
\hline Coal (imported) & & \multicolumn{7}{|c|}{ Energy savings (TL/m2) } & \\
\hline
\end{tabular}

Table 9. Optimum insulation thickness, energy savings and payback periods of Ardahan for various fuels

\begin{tabular}{|l|c|c|c|c|c|c|}
\hline \multirow{2}{*}{ Fuel type } & \multicolumn{7}{|c|}{ Ardahan } \\
\cline { 2 - 7 } & \multicolumn{7}{|c|}{ Optimum insulation thickness (m) } \\
\cline { 2 - 7 } & XPS & EPS & PUR & PIR & RW & GW \\
\hline Natural gas & 0,089 & 0,124 & 0,062 & 0,066 & 0,190 & 0,153 \\
\hline LPG (propan) & 0,221 & 0,307 & 0,158 & 0,165 & 0,451 & 0,370 \\
\hline Motorin & 0,213 & 0,295 & 0,152 & 0,159 & 0,435 & 0,356 \\
\hline Electricity & 0,183 & 0,254 & 0,130 & 0,136 & 0,375 & 0,306 \\
\hline Fuel-oil no.4 & 0,152 & 0,211 & 0,108 & 0,113 & 0,315 & 0,256 \\
\hline Coal (imported) & 0,109 & 0,152 & 0,077 & 0,081 & 0,230 & 0,186 \\
\hline & 88,02 & 88,98 & 87,25 & 88,07 & 92,82 & 90,69 \\
\hline Natural gas & 462,30 & 466,18 & 458,83 & 462,55 & 478,95 & 472,23 \\
\hline LPG (propan) & 429,66 & 433,36 & 426,36 & 429,89 & 445,56 & 439,13 \\
\hline Motorin & 321,78 & 324,82 & 319,08 & 321,97 & 335,00 & 329,61 \\
\hline Electricity & 228,54 & 230,91 & 226,47 & 228,69 & 239,04 & 234,70 \\
\hline Fuel-oil no.4 & 125,74 & 127,17 & 124,55 & 125,83 & 132,41 & 129,56 \\
\hline Coal (imported) & & \multicolumn{7}{|c|}{ Payback period (years) } & & \\
\hline & 0,302 & 0,280 & 0,322 & 0,301 & 0,297 & 0,168 \\
\hline Natural gas & 0,144 & 0,132 & 0,155 & 0,143 & 0,137 & 0,078 \\
\hline LPG (propan) & 0,149 & 0,136 & 0,160 & 0,148 & 0,141 & 0,081 \\
\hline Motorin & 0,170 & 0,156 & 0,183 & 0,169 & 0,162 & 0,093 \\
\hline Electricity & 0,199 & 0,183 & 0,214 & 0,198 & 0,191 & 0,109 \\
\hline Fuel-oil no.4 & 0,260 & 0,240 & 0,278 & 0,259 & 0,252 & 0,144 \\
\hline Coal (imported) &
\end{tabular}




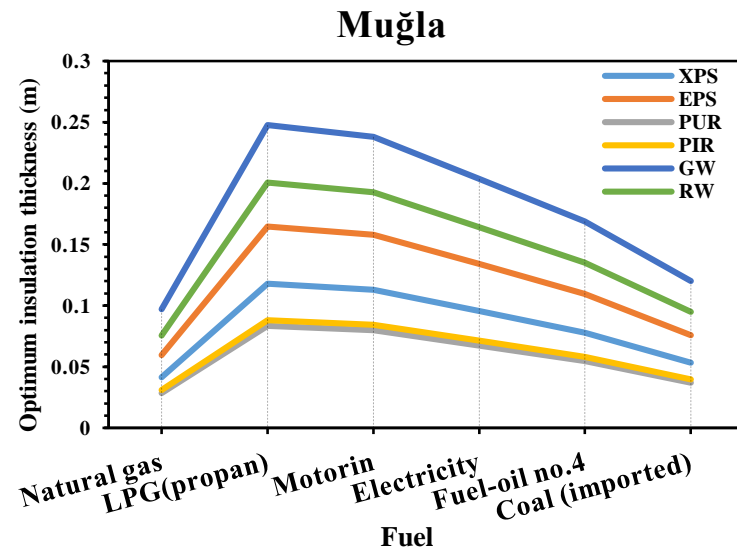

Ankara

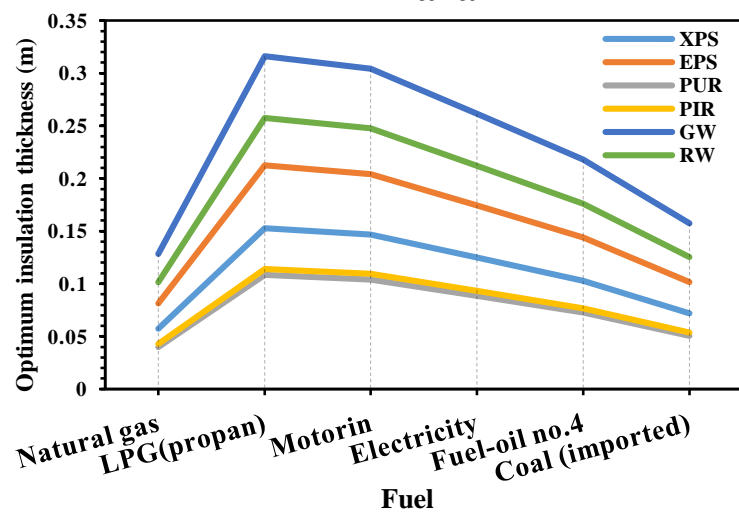

\section{Kocaeli}

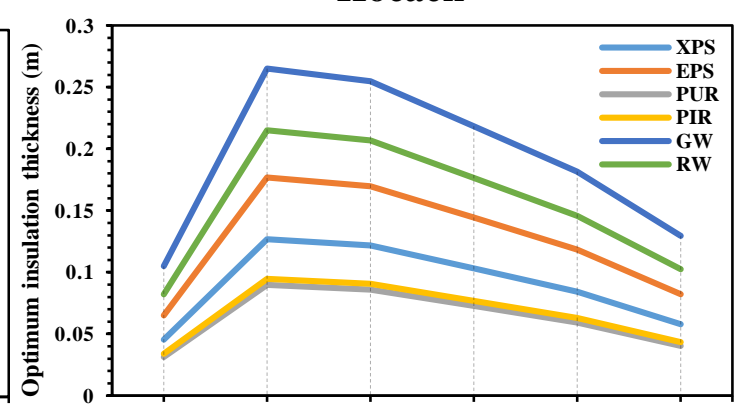

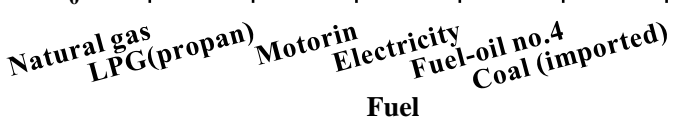

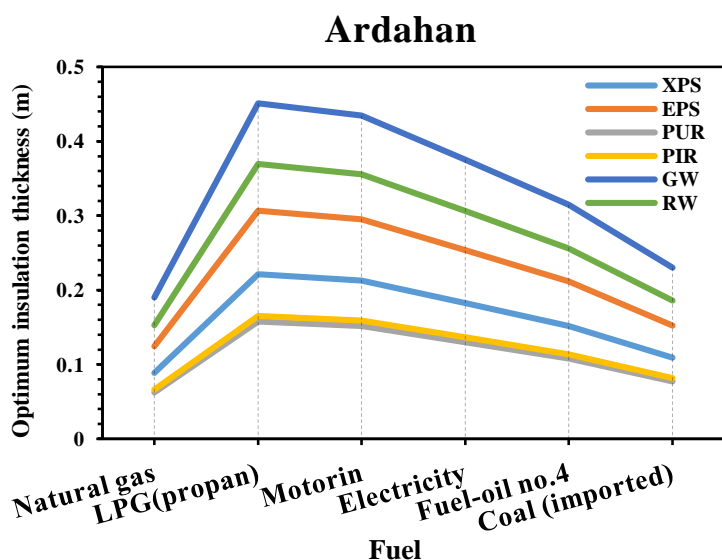

Fig. 5. Optimum insulation thickness versus various heating systems for different insulation materials in cities of Muğla, Kocaeli, Ankara, and Ardahan.

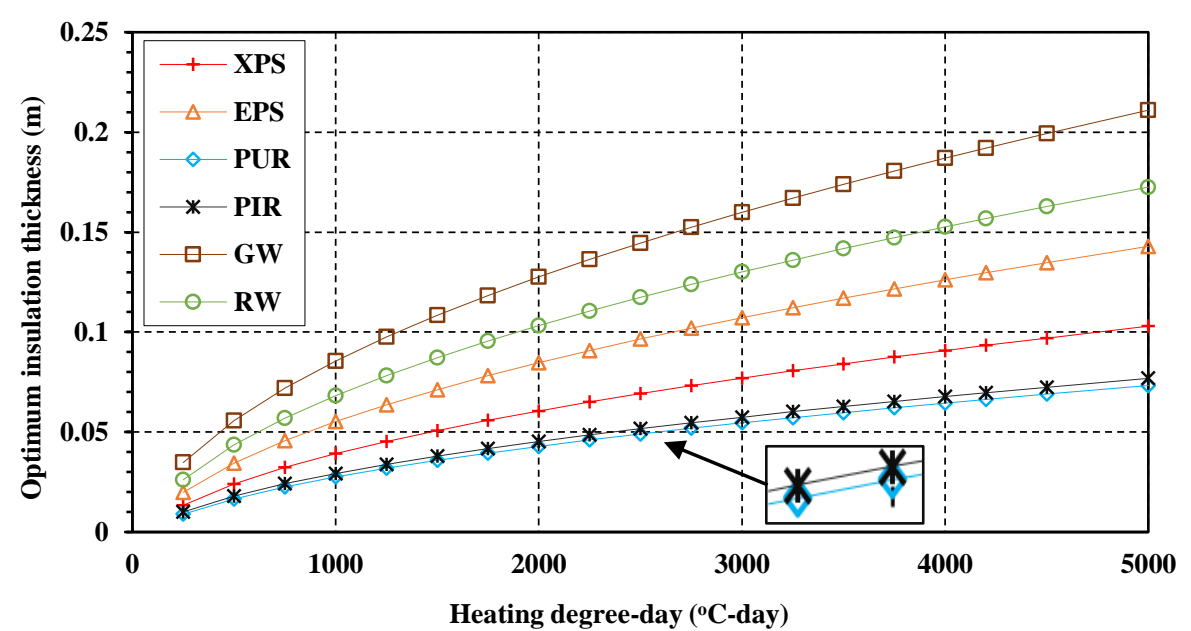

Fig. 6. Alteration of optimum insulation thickness depending on HDDs for different insulation materials in case of utilizing natural gas as an energy source.

\section{Conclusions}

Thermal insulation is based on two main issues: energy use and the environment. Energy use is a strategic, macro concept in all countries. For example, Turkey is not rich in terms of energy sources, with $60 \%$ of its energy requirements being imported from other countries. This is enhancing at an annual rate of $4.4 \%$ [6]. Reductions in heating needs can be achieved by minimizing heat losses, so the outer walls of buildings must be insulated with appropriate insulation materials. These materials are indispensable in the construction of energy efficient buildings; however, achieving the full energy savings potential requires the determination of a solution that optimizes insulation thickness, insulation costs and energy savings.

In this study, insulation material was examined to detect its optimum thickness, as well as its energy savings over a period of 15 years; this includes payback periods in the cities 
selected from four different climate regions in Turkey. While calculations were made, six types of energy fuel and insulation materials were considered for sandwich-type wall structure.

The results verify that the optimum insulation thicknesses ranges from 4.1-22.1 cm for XPS, 6-30.7 $\mathrm{cm}$ for EPS, $2.8-15.8 \mathrm{~cm}$ for PUR, 3.1-16.5 $\mathrm{cm}$ for PIR, 9.7-45.1 cm for RW and 7.6-37 cm for GW. The amount of energy savings ranged from $16.8-462.3 € / \mathrm{m}^{2}$ for XPS, $17.4-466.2 € / \mathrm{m}^{2}$ for EPS, $16.4-458.8$ $/ \mathrm{m}^{2}$ for PUR, $16.9-462.6$ $/ \mathrm{m}^{2}$ for PIR, 19.8-479 $€ / \mathrm{m}^{2}$ for RW and $18.4-472.2 € / \mathrm{m}^{2}$ for GW. The payback periods ranged from $0.078-0.860$ years. Based on these data, the greatest energy savings for the four cities is achieved using LPG. Furthermore, the insulation optimum thickness on the exterior walls of the building varies according to the number of heating degree-days and the insulation material used. The increase in fuel costs clearly demonstrates the importance of insulation in residential buildings. Insulation is also necessary for a greater sensitivity to environmental issues, in order to reduce the amount of energy used for heating purposes and the consequent emissions of flue gases into the environment.

\section{References}

[1] A. Aytac \& U.T. Aksoy, Enerji Tasarrufu iç ve Dış Duvarlarda Optimum Yalıtım Kalınlığı ve Isıtma Maliyeti ilişkisi, J. Gazi Univ. Fac. Eng. Archit., vol. 21, pp. 753-758, 2006.

[2] T. Keskin, "Enerji Verimliliği Kanunu ve Uygulama Süreci", Mühendis ve Makina vol. 569, pp. 106-112, 2007.

[3] N. Evcil, "Isı İzolasyonu ve Dış Duvarların Enerji Etkin Yenilenmesi", Yüksek Lisans Tezi, İstanbul Teknik Üniversitesi Fen Bilimleri Enstitüsü, İstanbul, 2000.

[4] İzocam Tic. San. A.Ş., Is1-Teknik-Ses-Yangın Yalıtımı, İzocam Ticaret ve Sanayi A.Ş. Yayınları, İstanbul, 2002.

[5] A. Dombayc1, M. Gölcü \& Y. Pancar, "Optimization of insulation thickness forexternal walls using different energysources", Applied Energy, vol. 83, pp. 921-928, 2006.

[6] K. Çomaklı \& B. Yüksel, "Optimum insulation thickness of external walls for energy saving", Applied Thermal Engineering, vol. 23, pp. 473-479, 2003.

[7] A. Bolattürk, "Optimum insulation thickness for building walls with respect to cooling and heating degree-hours in the warmest region of Turkey", Building and Environment, vol. 43, pp. 1055-1064, 2008.

[8] O. Kaynakl1, "A study on residential heating energy requirement and optimum insulation thickness", Renewable Energy, vol. 33, pp. 1164-1172, 2008.

[9] O. Kaynaklı \& R. Yamankaradeniz, "Isıtma Süreci ve Optimum Yalıtım Kalınlığı Hesabı", VIII. Ulusal Tesisat Mühendisliği Kongresi, pp. 187-195, 2007.

[10] M. Gölcü, A. Dombaycı \& S. Abalı, "Denizli için Optimum Yalıtım Kalınlığının Enerji Tasarrufuna Etkisi ve Sonuçları", Gazi Üniversitesi Müh. Mim. Fak.Dergisi, vol. 21, pp. 639-644, 2006.

[11] A. Uçar \& F. Balo, "Determination of the energy savings and the optimum insulation thickness in the four different insulated exterior walls", Renewable Energy, vol. 35, pp. 88-94, 2010.

[12] O. Kon \& B. Yüksel, "Konut D1şı Kompleks Yapılar için Optimum Yalıtım Kalınlığı", 18. Ulusal Isı Bilimi ve
Tekniği Kongresi, ULIBTK'11, Zonguldak, pp. 604-610, (07-10 Eylül 2011).

[13] D. B. Özkan \& C. Onan, "Optimization of insulation thickness for different glazing areas in buildings for various climatic regions in Turkey", Applied Energy, vol. 88, pp. 1331-1342, 2011.

[14] T.M.I. Mahlia, B. N. Taufiq \& H. H. Masjuki, "Correlation between thermal conductivity and the thickness of selected insulation materials for building Wall", Energy and Buildings, vol. 39, pp. 182-187, 2007.

[15] N. A. Kürekçi, "Determination of optimum insulation thickness for building walls by using heating and cooling degree-day values of all Turkey's provincial centers", Energy and Buildings, vol. 118, pp. 197-213, 2016.

[16] A. Ulaş, "Binalarda TS 825 Hesap Yöntemine Göre Is1 Kaybı, Yakıt Tüketimi, Karbondioksit Emisyonu Hesabı ve Maliyet Analizi", Gazi Üniversitesi Fen Bilimleri Enstitüsü, Yüksek Lisans Tezi, Ankara, 2010.

[17] A. Hasan, "Optimizing Insulation Thickness for Buildings Using Life Cycle Cost", Applied Energy, vol. 63, pp. 115$124,1999$.

[18] M. Ozel \& K. Pihtili, "Determination of optimum insulation thickness by using heating and cooling degreeday values", J. Eng. Nat. Sci, vol. 26, pp. 191-197, 2008.

[19] A. Gürel \& A. Daşdemir, "Türkiye'nin Dört Farklı İklim Bölgesinde Isıtma ve Soğutma Yükleri İçin Optimum Yalıtım Kalınlıklarının Belirlenmesi", Erciyes Üniversitesi Fen Bilimleri Enstitüsü Dergisi, vol. 27, pp. 346-352, 2011.

[20] H. Sarak \& A. Satman, "The degree-day method to estimate the residential heating natural gas consumption in Turkey: a case study", Energy, vol. 28, pp. 929-939, 2003.

[21] N. Sisman, E. Kahya, N. Aras \& H. Aras, "Determination of optimum insulation thicknesses of the external walls and roof (ceiling) for Turkey's different degree-day regions", Energy Policy, vol. 35, pp. 5151-5155, 2007.

[22] A. E. Gürel \& A. Daşdemir, "Türkiye'nin dört farklı iklim bölgesinde 1sıtma ve soğutma yükleri için optimum yalıtım kalınlıklarının belirlenmesi", Erciyes Üniversitesi Fen Bilimleri Enstitüsü Dergisi, vol. 27, pp. 346-352, 2016.

[23] N. A. Kurekci, "Determination of optimum insulation thickness for building walls by using heating and cooling degree-day values of all Turkey's provincial centers", Energy and Buildings, vol. 118, pp. 197-213, 2016.

[24] TSE (Turkish Standards Institution). TS 825: Thermal Insulation in Buildings; 1998.

[25] N. Daouas, Z. Hassen \& H. B. Aissia, "Analytical period solution for the study of thermal performance and optimum insulation thickness of building walls in Tunisia", Appl Thermal Eng, vol. 30, pp. 319-326, 2010.

[26] M. Tolun, "Farklı derece-gün bölgeleri için yalıtım probleminin incelenmesi", PhD Thesis. Enerji Enstitüsü, 2017.

[27] A. Aytaç \& U. T. Aksoy, "Enerji Tasarrufu İçin Diş Duvarlarda Optimum Yalıtım Kalınlığı ve Isıtma Maliyeti İlişkisi", Gazi Üniversitesi Mühendislik Mimarlık Fakültesi Dergisi, vol. 21, pp. 753-758, 2006. 